TITLE:

\title{
The influence of psychotic states on the autonomic nervous system in schizophrenia(Abstract_要旨)
}

\author{
$\operatorname{AUTHOR(S):~}$ \\ Toichi, Motomi
}

\section{CITATION:}

Toichi, Motomi. The influence of psychotic states on the autonomic nervous system in schizophrenia. 京都大学, 1999, 博士(医学)

ISSUE DATE:

1999-01-25

URL:

http://hdl.handle.net/2433/182277

RIGHT: 


\section{【192】}

\begin{tabular}{|c|c|}
\hline 名 & 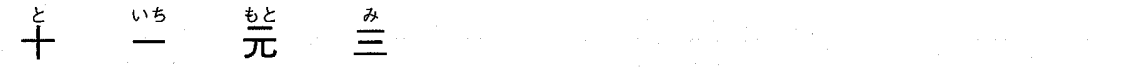 \\
\hline 学位 (専攻分野) & 士（医 学） \\
\hline 学 位記 番 号 & 医 博 第 2062 号 \\
\hline 学位授与の日付 & 平成 11 年 1 月 25 日 \\
\hline 学位授与の要件 & 学 位 規則第 4 条第 1 項 該 当 \\
\hline 究科 · 専攻 & 医学研究科脳統御医科学系専攻 \\
\hline 位論文題目 & $\begin{array}{l}\text { The influence of psychotic states on the autonomic nervous system } \\
\text { schizophrenia }\end{array}$ \\
\hline
\end{tabular}

（精神分裂病において精神症状が自律神経に与える影響）

(主查)

論文調查委員 教 授柴崎 浩 教授篠山重威 教 授三好功峰

論文内容 の 要旨

精神分裂病において自律神経機能の異常を示唆する所見はこれまでに報告されているが，それが精神分裂病の生得的障害 であるのか，精神分裂病症状による二次的障害であるのかは明らかにはされていない。また，精神分裂病の自律神経機能に ついて，交感神経機能，副交感神経機能を区別して調べた報告はみられない。精神症状を有する患者の自律神経機能を非侵 襲的に評価するため, 先行研究において, 短時間の心拍間隔測定をもとに交感・副交感神経機能を個別に評価できる心拍変 動解析法を創案した。本研究では，その方法を用いて，精神分裂病において精神症状が心拍を制御する自律神経に与える影 響を調べた。

対象は本研究の参加に同意の得られた慢性精神分裂病患者53名および年齢と性別を個人的に一致させた健常者 53 名から なる対照群である。患者群は，軽度ないし中等度の精神症状を有しており，循環器系の影響が少ない薬剤のみを服用してい る入院患者である。患者群に対して，投薬内容の変更を行わない 8 週間の調査期間を設け, この期間の最初と最後の 2 度に わたり，精神症状と自律神経機能の評価を行った。精神症状については，陽性陰性症状評価尺度を用いて，幻覚，妄想など の陽性症状 7 項目，感情の平板化や引きこもりなどの陰性症状 7 項目，緊張や抑うつなどの一般精神病理16項目について面 接を行って評価した。自律神経機能については，上記の面接に続いて心電図П誘導を用いた心拍間隔の連続測定を行い，そ れをもとにに平均心拍間隔を算出するとともに，上述の心拍変動解析法を用いて交感神経機能と副交感神経機能をそれぞれ 評価した。対照群に対しては自律神経機能の評価のみを行った。

その結果，対照群と患者群との間には，平均心拍間隔，交感神経機能の定量的指標（CSI），副交感神経機能の定量的指 標（CVI）のいずれにも有意差がみられなかった。患者群のうち，2 度の評価で精神症状が変化した者は53名中22名（改善 12名，増悪10名）であった。精神症伏が変化しなかった 31 名では，平均心拍間隔，CSI，CVIのいずれも 2 度の評価の間で 有意差を生じなかった。次に, 精神症状の変化した 22 名において, 精神症状がより軽度な時点とより著明な時点を個人内比 較した。より軽度な時に比べ，より著明な時には，平均心拍閒隔は軽度ながら有意に短縮し，CVIは有意に低下したが， CSIは有意な変化を示さなかった。直線回帰分析では, CVIの変化と陽性陰性症状評価尺度総合得点の変化との間には有意 な相関が認められたが，陽性陰性症状評価尺度に含まれる 3 つ下位カテゴリー（陽性症状，陰性症状，一般精神病理）内 の得点変化を説明変数に用いた重回帰分析では，いずれの下位カテゴリーも単独では有意な相関を示さなかった。精神症状 の変化した 22 名のうち,「緊張」や「恐怖」など情動を調べる項目で変化のみられた 8 名を除いた場合でも, 精神症伏にと もなうCVIの変化は有意であった。

結果を要約すると，心拍を制御する自律神経機能に関して，精神分裂病患者は対照群とは異ならなかった。しかし，精神 分裂病患者において, 精神症状は自律神経に影響を与えており, 精神症状が増悪すると副交感神経機能が低下した。従って, これまで精神分裂病で報告されてきた自律神経機能障害の一部は，精神症状により二次的にもたらされたものであると考え 
られた。

論 文審査の結果の要旨

本研究は, 新しく開発した心拍間隔の変動の数学的解析を行うことによる心自律神経機能検査によって, 精神分裂病患者 における精神症状の自律神経機能への影響を明らかにすることを目的としたものである。この心拍変動解析法によって測定 される心交感神経指数（CSI） と心副交感神経指数（CVI）などの自律神経機能について，慢性の精神分裂病患者群と年齢・ 性別を一致させた健常対照群との差異, 精神分裂病患者における精神症状の変化との関係，および，精神分裂病の症状を陽 性症状，陰性症状，その他の非特異的な症状の 3 群に分けたときのそれぞれの精神症状群との関係を検討した。

その結果, 精神分裂病における疾患特異的な自律神経異常や, 精神症状の各群に特徵的な自律神経異常はみられないが, 精神症状の悪化に伴って副交感神経機能の有意の低下が認められた。このことから，精神分裂病における精神症状そのもの が副交感神経に対して抑制的に働くことが明らかにされた。

以上の研究は, 精神状態と自律神経活動の関係の解明に貢献し, 精神分裂病の理解に寄与するところが多い。

したがって, 本論文は博士 (医学) の学位論文として価値あるものと認める。

なお，本学位授与申請者は，平成10年12月 7 日実施の論文内容とそれに関連した試問を受け，合格と認められたものであ る。 